\title{
Peptide profiling of goat milk fermented by Lactobacillus delbrueckii ssp. delbrueckii BD7: Identification of potential biological activity
}

\author{
YULIANA TANDI RUBAK ${ }^{1, \bullet}$, LILIS NURAIDA ${ }^{2,3, \bullet \vartheta}$, DYAH ISWANTINI ${ }^{4,5}$, ENDANG PRANGDIMURTI $^{2,3}$, \\ MAXS URIAS EBENHAIZAR SANAM ${ }^{6}$

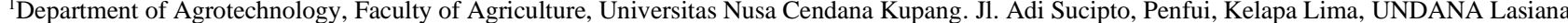 \\ Campus, Kupang City 85001, East Nusa Tenggara, Indonesia. Tel./fax. +62-380-881085, `email: Rubakyuliana@ yahoo.co.id \\ ${ }^{2}$ Department of Food Science and Technology, Institut Pertanian Bogor. Jl. Raya Dramaga, IPB Dramaga Campus, Bogor 16680, West Java, Indonesia. \\ Tel./fax.+62-251-8623203, " email:Inuraida@gmail.com \\ ${ }^{3}$ Southeast Asian Food and Agricultural Science and Technology (SEAFAST) Center, Institut Pertanian Bogor. Jl. Raya Dramaga, IPB Dramaga \\ Campus, Bogor 16680, West Java, Indonesia. \\ ${ }^{4}$ Department of Chemistry, Institut Pertanian Bogor. Jl. Raya Dramaga, IPB Dramaga Campus, Bogor 16680, West Java, Indonesia \\ ${ }^{5}$ Tropical Biopharmaca Research Center, Institut Pertanian Bogor. Jl. Taman Kencana, IPB Taman Kencana Campus, Bogor 16128, West Java, Indonesia. \\ ${ }^{6}$ Faculty of Veterinary Medicine, Universitas Nusa Cendana Kupang. Jl. Adi Sucipto, Penfui, Kelapa Lima, Undana Lasiana Campus, Kupang City \\ 85001, East Nusa Tenggara, Indonesia
}

Manuscript received: 18 May 2021. Revision accepted: 9 July 2021.

\begin{abstract}
Rubak YT, Nuraida L, Iswantini D, Prangdimurti E, Sanam MUE. 2021. Peptide profiling of goat milk fermented by Lactobacillus delbrueckii ssp. delbrueckii BD7: Identification of potential biological activity. Biodiversitas 22: 3136-3145. This study investigated the angiotensin-converting enzyme (ACE) inhibitory activity in fermented goat milk by Lactobacillus delbrueckii ssp. delbrueckii BD7, characterizing the peptide and its potential as a bioactive peptide. The starter culture (2\%) was inoculated into pasteurized goat skim milk (11\%), then incubated at $37{ }^{\circ} \mathrm{C}$ until it reached $\mathrm{pH} 4.6$. Centrifugation at $6000 \mathrm{~g} \mathrm{x} 10$ minutes at $4{ }^{\circ} \mathrm{C}$ was applied. The supernatant obtained was then ultrafiltrated using a membrane cut-off with a molecular weight of $3 \mathrm{kDa}$, and the fraction obtained was analyzed to determine the inhibitory activity of ACE. Peptides were characterized using Nano LC / MS / MS, and identification as bioactive peptides was carried out based on a literature review. ACE inhibitory activity of fermented goat milk of $L b$. delbrueckii ssp. delbrueckii BD7 was $55.98 \pm 3.53 \%$. A total of 157 peptides were released with molecular weights ranging from 770.78-2081.12 Da and having 7-19 amino acid residues. The main peptide was hydrolyzed from casein (72.6\%), cleavage in the parent protein, specific for aliphatic and aromatic amino acids. Identification of bioactive peptides based on the similarity of amino acid residues at C-terminal obtained 28 ACE inhibitor peptides, 19 antioxidant peptides, and ten antimicrobial peptides. Some of these peptides have homologous sequences with previously reported peptides. Lb. delbrueckii ssp. delbrueckii BD7 has the potential as a starter culture to produce fermented milk, which is rich in biological activity.
\end{abstract}

Keywords: Angiotensin, bioactive peptides, fermented goat milk, Lactic acid bacteria, Lb. delbrueckii ssp. delbrueckii BD7

\section{INTRODUCTION}

Bioactive peptides have been defined as certain parts or fragments of encrypted proteins in the primary protein sequence and positively impact the function or condition of the body to affect the overall health status of the human body. These health benefits have been linked to various biological activities of bioactive peptides in the cardiovascular, digestive, immune, and nervous systems (Li et al. 2019; Daliri et al. 2017). Bioactive peptides have several characteristics in terms of their order and molecular weight. The molecular weight of bioactive peptides is reported to be $<10 \mathrm{kDa}$, with amino acid residues of 2 to 20 (Li et al. 2017; Kim et al. 2016). Another characteristic that bioactive peptides have is specific amino acid residues at the C-terminal (Abdel-Hamid et al. 2017). Aliphatic and aromatic amino acids are the dominant amino acids in the C-terminal of a bioactive peptide. Proline, Arginine, and Lysine are the dominant amino acids in the C-terminal of ACE inhibitor peptides (Rai et al. 2017). Likewise, those found in antimicrobial bioactive peptides, antioxidants, and immunomodulatory peptides.

Foods with high protein content are known to be a source of bioactive peptides. Milk and dairy products, including fermented milk, have been identified as sources of bioactive peptides. The documentation of peptides produced from fermented milk includes immunomodulatory peptides (Zhao et al. 2014), anticancer (Ayyash et al. 2018; Elfahri et al. 2016), antimicrobial (Algboory et al. 2018; Retnaningrum et al. 2020), binding minerals (Zhao et al. 2015; Gaetano-Silva et al. 2015), antihypertensives and antioxidants (Rana et al. 2018; Georgalaki et al. 2017). Fermentation is an exciting approach to produce bioactive peptides from milk protein using microbes. Lactic acid bacteria (LAB) are the dominant bacteria involved during the fermentation process. During fermentation, LAB will actively hydrolyze proteins into amino acids and peptides for their growth needs. The peptides released vary in number and sequence of peptides, and among them are bioactive peptides. The release of these bioactive peptides in various fermented 
foods is strain-specific (Li et al. 2017; Wang et al. 2015). Protein hydrolysis by LAB involves a proteolytic system. One of the keys to protein hydrolysis in LAB proteolytic system is the Cell Envelope Protease (CEP). The components of CEP differ between LAB and can even be different in one species (Lozo et al. 2011; Raveschot et al. 2020), which impacts the specificity of cleavage in parent protein. CEP's difference has clearly explained why the peptides released varied both in number and sequence among LAB.

Certain LAB has been known to release bioactive peptides. Several strains of Lactobacillus and Lactococcus have been used as starter cultures to produce bioactive peptides (Chen et al. 2015; Barla et al. 2016). Cultures can be used alone or with other LAB (Chaves-López et al. 2014). The potential of LAB will continue to be explored because of the increasing human awareness of health. Through exploration, certain LAB strains can be obtained, which can be applied to produce functional food products that provide nutritional components and specific biological activities for the human body. This study aims to determine the angiotensin-converting enzyme's inhibitory activity in fermented goat milk by Lactobacillus delbrueckii ssp. delbrueckii BD7 characterized the resulting peptides and their potential as bioactive peptides. Lb. delbrueckii ssp. delbrueckii BD7 was isolated from kefir and had a high proteolytic activity based on our previous study results (Rubak et al. 2020).

\section{MATERIAL AND METHODS}

\section{Culture}

Lactobacillus delbrueckii ssp. delbrueckii BD7 was obtained from Southeast Asian Food and Agricultural Science and Technology (SEAFAST) Center, IPB University (Bogor Agricultural University), Bogor, Indonesia. LAB stock cultures were freshened in De Man Rogosa and Sharpe (MRS) broth (Oxoid, USA) and incubated at $37^{\circ} \mathrm{C}$ for 24 hours. $2 \%$ of LAB in MRS broth was transferred into reconstituted goat milk and incubated at $37^{\circ} \mathrm{C}$ for $24 \mathrm{~h}$. This adaptation stage was carried out twice.

\section{Fermentation of goat milk}

The starter culture (2\%) was inoculated into pasteurized goat skim milk (11\%, Sukamilk, Dutch) and then incubated at $37^{\circ} \mathrm{C}$ until pH 4.6 was reached (700 Eutech). Fermentation was stopped by heating at $75{ }^{\circ} \mathrm{C}$ for 1 minute; then fermented goat milk was centrifuged (Hettich, Zentrifugen, Mikro 22R) at $6000 \mathrm{gx} 10$ minutes at $4{ }^{\circ} \mathrm{C}$. The supernatant was collected, followed by ultrafiltration using a molecular weight membrane cut of $3 \mathrm{kDa}$ (Merck, Amicon Ultra-4 mL, Centrifugal Filter, IRL). The supernatant was put into a filter tube and centrifuged at $4000 \mathrm{xg}, 30$ minutes, $4{ }^{\circ} \mathrm{C}$. Fractions were collected to determine ACE inhibitory activity (Chusman 1971).

\section{In vitro assay for inhibitory activity}

Hippuryl-L-Histidyl-L-Leucine (HHL, Sigma, USA) was used as an enzyme substrate. A total of $50 \mu \mathrm{L}$ of the sample was mixed with $50 \mu \mathrm{L}$ of substrate $[50 \mathrm{mM}$ HHL in $0.1 \mathrm{M}$ sodium borate buffer $(\mathrm{pH} 8.3)$ containing $0.3 \mathrm{M}$ $\mathrm{NaCl}]$ and incubated at $37{ }^{\circ} \mathrm{C}$ for $5 \mathrm{~min}$. A total of $50 \mu \mathrm{L}$ of $0.1 \mathrm{U} \mathrm{mL}^{-1}$ ACE solution (Rabbit lung, Sigma, USA) was added, then incubated at $37^{\circ} \mathrm{C}$ for $5 \mathrm{~min} .250 \mu \mathrm{L}$ of $1 \mathrm{M}$ $\mathrm{HCl}$ solution was added to stop the reaction. Then, $1.5 \mathrm{~mL}$ of ethyl acetate was added to extract the hippuric acid (HA) released by ACE from the reaction mixture using vortex mixing for $10 \mathrm{~s}$ followed by centrifugation at $2000 \times \mathrm{g}$ for $5 \mathrm{~min}$. The $0.8 \mathrm{~mL}$ ethyl acetate layer was transferred to a clean tube and evaporated at $85{ }^{\circ} \mathrm{C}$ for $60 \mathrm{~min}$. The HA in the tube was dissolved in $4 \mathrm{~mL}$ of distilled water and cooled to room temperature. At an optical density of 228 $\mathrm{nm}$, the amount of HA formed was measured (UV-2800, Hitachi, JPN). The inhibition rate was calculated as $100 \%$ [(B-A) / B], where A is the optical density in the presence of $\mathrm{ACE}$ and $\mathrm{ACE}$ inhibitor components, and $\mathrm{B}$ is the optical density without the ACE inhibitor component.

\section{Identification of peptides by mass spectrometry}

Identification of the peptides was done using the liquid chromatography-mass spectrometry (LC-MS), Nano LC Ultimate 3000 series system Tandem Q Exactive Plus Orbitrap HRMS (Thermo scientific, GER), with $5 \mu \mathrm{L}$ sample, a Thermo scientific trap column $(164649,30 \mu \mathrm{m} x$ $5 \mathrm{~mm}$ ) and an eluent of a gradient of $98 \%$ solvent $\mathrm{A}$ [water/acetonitrile $(98: 2, \mathrm{v} / \mathrm{v}), 0.1 \%$ formic acid] and $2 \%$ solvent B [Water/acetonitrile (2:98, v/v), $0.1 \%$ formic acid] at a flow rate of $5 \mu \mathrm{L} / \mathrm{min}$ for $6 \mathrm{~min}$. The peptides were separated on a capillary column (PepMap RSLC-C18, 75$\mu \mathrm{m} \times 150 \mathrm{~mm}, 3.5 \mu \mathrm{m}$ particle size, 100 pore size, Thermo Scientific ES800) at a flow rate of $300 \mathrm{~nL} / \mathrm{min}$ with a gradient at $2 \%$ to $35 \%$ solvent B over $30 \mathrm{~min}$, then from $35 \%$ to $90 \%$ over ten min, followed by the final step with solvent B (90\%) over 5 minutes to solvent B (5\%) over 5 minutes. Electrospray was carried out at an ion spray voltage of $3500 \mathrm{eV}$. The MS/MS spectrum was collected from 200 to $2000 \mathrm{~m} / \mathrm{z}$. Through Proteomic Discoverer software version 2.2. peptides in the sample are identified.

\section{RESULT AND DISCUSSION}

\section{ACE inhibitory activity in fraction separated according to molecular weight by ultrafiltration}

Two fractions namely fraction $<3 \mathrm{kDa}$ and $>3 \mathrm{kDa}$ were obtained from the ultrafiltration of goat's milk supernatant fermented by Lb. delbrueckii ssp. delbrueckii BD7 uses 3 kDa Molecular Weight Cut Off (MWCO). Measurement of ACE inhibitory activity in the two fractions is presented in Table 1. The results showed that the ACE inhibitory activity in the $<3 \mathrm{kDa}$ fraction $(55.98 \pm 3.53 \%)$ was higher than the $>3 \mathrm{kDa}$ fraction.

The results obtained reaffirmed that the highest ACE inhibitory activity was generally in the $<3 \mathrm{kDa}$ fraction as reported by previous researchers (Fan et al. 2018; MorenoMontoro et al. 2018). Several researchers have reported 
Delbrueckii species producing ACE inhibitory activity, with activity above $50 \%$. Lb. delbrueckii. subsp. bulgaricus 92059 (Li et al. 2019), Lb. delbrueckii subsp. bulgaricus ACA-DC 87 (Georgalaki et al. 2017), Lb. delbrueckii QS306 (Wu et al. 2019) and Lb. bulgaricus LB6 (Shu et al. 2019). A previous study by (Qian et al. 2011) and (Villegas et al. 2015) reported ACE inhibitory activity of $L b$. delbrueckii ssp. bulgaricus LB340 and Lb. delbrueckii subsp. lactis CRL 58. In addition to being strain-specific, the use of substrates also affects ACE inhibitory activity (Wang et al. 2016; Georgalaki et al. 2017). Several researchers have reported that goat milk has ACE inhibitory activity (Ibrahim et al. 2017; Izquierdo-González et al. 2019).

Identification of peptides generated from goat milk fermented by Lb. delbrueckii ssp. delbrueckii BD7 in the <3 kDa fraction

During fermentation, through its proteolytic system, LAB actively hydrolyzes proteins into peptides and free amino acids, some of which will be brought into the cell as a source of nitrogen for metabolism. Some peptides will accumulate on the substrate (Fan et al. 2019). A total of 157 peptides (data not presented) were released in fermented goat milk by Lb. delbrueckii ssp. delbrueckii BD7 ( $<3 \mathrm{kDa}$ ), during incubation $48 \mathrm{~h}$ at $37{ }^{\circ} \mathrm{C}$. Most of peptides were hydrolyzed from casein as much as $72.6 \%$ ( $\alpha$ S 1 -casein 9.6\%, $\alpha \mathrm{S} 2$-casein $14.6 \%, \beta$-casein $43.3 \%$, and $\kappa$-casein $5.1 \%$ ), others were hydrolyzed from whey as much $32.4 \%$ ( $\alpha$-lactalbumin 1.9\%, $\beta$-lactoglobulin $3.8 \%$, and serum amyloid A $21.7 \%$ ). Peptide profile of fermented goat milk by $L b$. delbrueckii ssp. delbrueckii BD7 is summarized in Table 2. The amount of hydrolyzed peptides in this study was seen at the chromatogram peak using Nano LC / MS.MS (Figure 1).

The protein in goat milk consists of casein $(80 \%)$ and whey $(20 \%)$. Casein is a major source of amino acids and peptides (Karami et al. 2019). $\beta$-casein is the dominant parent protein in goat milk, about $54.8 \%$ of total casein (Selvaggi et al. 2014). Most of the peptides released by $L b$. delbrueckii ssp. delbrueckii BD7 in fermented goat milk are derived from the cleavage of the parent protein $\beta$-casein (Table 2). Similar results have been reported in the studies of Ali et al. (2019) and Kliche et al. (2017). The flexible and open structure of $\beta$-casein facilitates the accessibility of CEP Lb. delbrueckii ssp. delbrueckii BD7. Additionally, Ji et al. (2021) stated that the CEP properties of $L b$. delbrueckii is a zinc-dependent monomer $\sim 70 \mathrm{kDa}$, which degrades intact casein with a significant preference for $\beta$ casein. However, during fermentation, peptides could also be hydrolyzed from other protein parents in relatively small amounts. The number of peptides released from each parent protein varied, highly strain-dependent. Not all $L b$. delbrueckii is able to hydrolyze casein. Kliche et al. (2017) reported that Lb. delbrueckii ssp. bulgaricus 92059 could not hydrolyze $\kappa$-casein. Proteolytic activity determines the ability of protein hydrolysis by LAB. Lactic Acid Bacteria have a complex proteolytic system, which involves at least three main components: CEP, specific transporters, and intracellular peptidase (Savijoki et al. 2006). The LAB proteolytic system's complexity is indicated by the parent protein specificity, which is cleaved to produce various peptides from milk protein.

The peptide released by Lb. delbrueckii ssp. delbrueckii BD 7 has a molecular weight of 770.78-2081.12 Da, with the shortest peptide length consisting of 7 amino acids ( $\beta$ casein, K-casein, $\alpha$-lactalbumin, and serum amyloid A) and the longest with 19 amino acid residues ( $\alpha$ s1-casein). The peptide length identified from $L b$. delbrueckii could consist of 3 to 20 amino acids (Villegas et al. 2014).

Table 1. Angiotensin-converting enzyme inhibitory activity in fractions $>3 \mathrm{kDa}$ and $<3 \mathrm{kDa}$ of fermented goat milk by $L b$. delbrueckii ssp. delbrueckii $\mathrm{BD} 7$

\begin{tabular}{lcc}
\hline \multicolumn{1}{c}{$\begin{array}{c}\text { Lactic acid } \\
\text { bacteria }\end{array}$} & \multicolumn{2}{c}{ ACE inhibitory activity (\%) } \\
\cline { 2 - 3 } Lb. delbrueckii \\
$\begin{array}{l}\text { Ssp. delbrueckii } \\
\text { BD7 }\end{array}$ & $28.81 \pm 1.87$ & $<5$ kDa \\
\hline
\end{tabular}

Table 2. Peptide profiles of $<3 \mathrm{kDa}$ fraction of fermented goat milk of Lb. delbrueckii ssp. delbrueckii BD7

\begin{tabular}{|c|c|c|c|c|c|}
\hline Parent protein* & Total peptides & $\begin{array}{l}\text { Amino acid } \\
\text { residue }\end{array}$ & $\mathrm{MH}+[\mathrm{Da}]$ & $\mathbf{m} / \mathbf{z}[\mathbf{D a}]$ & Dominant peptide \\
\hline$\alpha$ s1-casein & 15 & $7-19$ & $940.47-1844.86$ & $940.47-1844.85$ & FSDIPNPIGSENSGKTTMP \\
\hline$\alpha$ s2-casein & 23 & $8-17$ & $990.48-2081.12$ & $990.48-2081.10$ & ITVDDKHY \\
\hline$\beta$-casein & 68 & $7-16$ & $770.48-2081.12$ & $770.47-1966.88$ & QQQTEDELQDKIHP, TEDELQDKIHP \\
\hline $\mathrm{K}$-casein & 8 & $7-11$ & $803.44-1268.65$ & $400.20-634.83$ & FLPYPYY \\
\hline$\alpha$-lactalbumin & 3 & $7-10$ & $905.43-1126.47$ & $905.43-1126.47$ & FHTSGYDTQA \\
\hline$\beta$-lactoglobulin & 6 & $8-11$ & $903.56-1270.69$ & $903.55-1270.68$ & TKIPAVFK \\
\hline Serum amyloid A & 34 & $7-17$ & $833.47-1938.93$ & $833.47-1938.91$ & ITDPLFKG \\
\hline
\end{tabular}

Note: A: Alanine, D: Aspartic Acid, E: GlutamicAcid, F: Phenylalanine, G: Glysin, I: Isoleucine, K: Lysine, L: Leucine, M: Methionine, N: Asparagine, P: Proline, Q: Glutamine, R: Arginine, S: Serine, T: Threonine, V: Valine, W: Tryptophan, Y: Tyrosine. *Protein access code at https://www.uniprot.org/. 


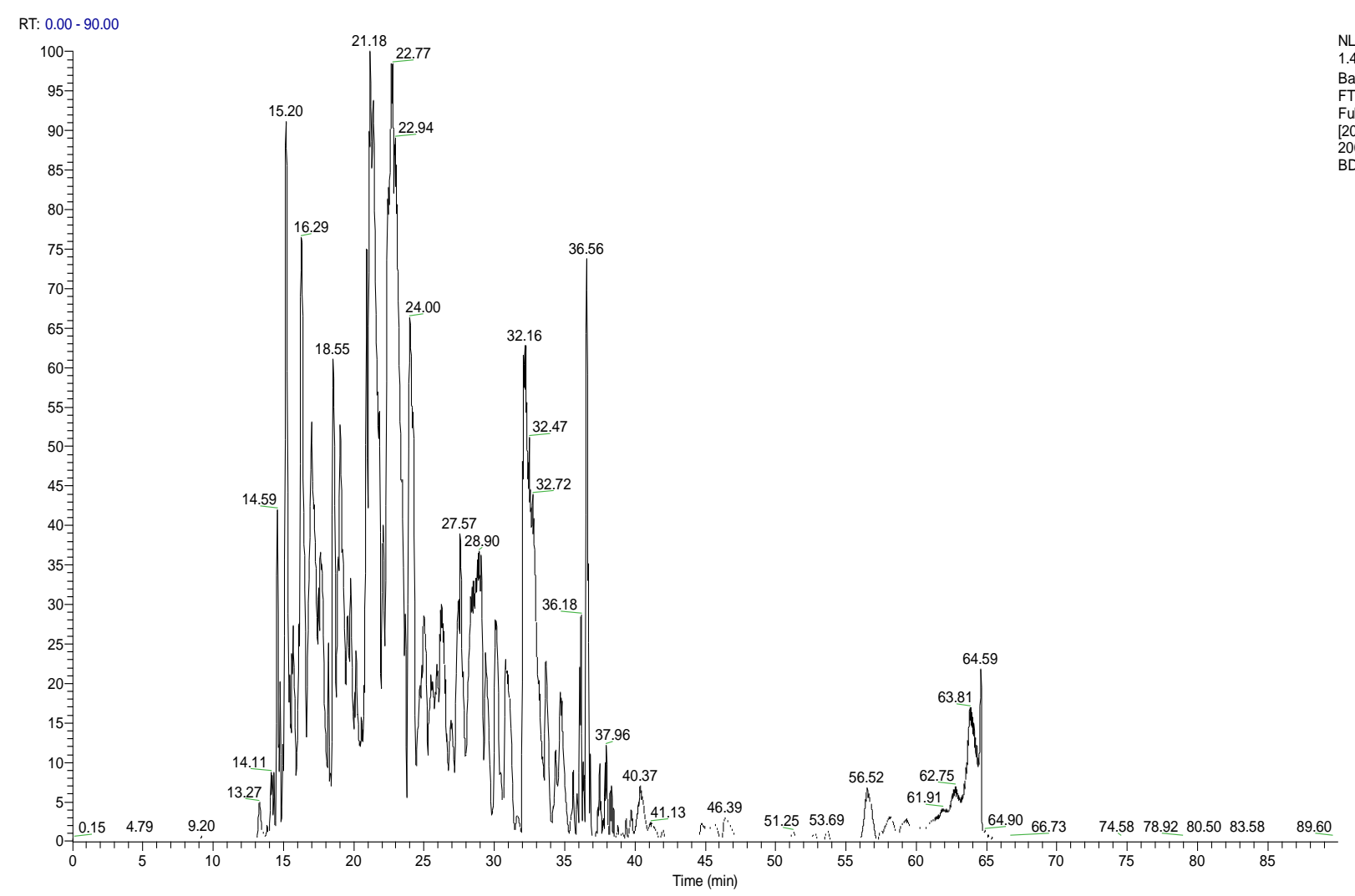

Figure 1. Nano LC-MS/MS mass spectra of goat milk fermented by Lb. delbrueckii ssp. delbrueckii BD7 in a mass range from m/z 2002000

Some researchers stated that fermentation conditions such as temperature and fermentation time could also affect the peptide variations produced by LAB (Chen et al. 2015; Li et al. 2017; Shu et al. 2015). LAB growth conditioning under optimal conditions will result in maximum protein hydrolysis. In our study, goat milk fermentation was carried out at $37^{\circ} \mathrm{C}$, and fermentation was stopped when $\mathrm{pH} 4.6$ was reached. Lactobacillus delbrueckii had a growth temperature variation between $37-42{ }^{\circ} \mathrm{C}$. In the research of Villegas et al., 2014, Lb. delbrueckii subsp. lactis CRL 58 grew well at $40{ }^{\circ} \mathrm{C}$, others grow at $37{ }^{\circ} \mathrm{C}$ (Georgalaki et al. 2017; Shu et al. 2018) and $42^{\circ} \mathrm{C}$ (Shi et al. 2017). The $\mathrm{pH}$ during fermentation is also a concern. High acidification is thought to inhibit or stop the protein hydrolysis process so that some researchers then stop fermentation when $\mathrm{pH} 4.5$ has been reached (Chen et al. $2015)$. This is related to the sensitivity of the protease to acidification.

Cell envelope proteinase is an extracellular proteolytic enzyme from LAB responsible for the first step in the hydrolysis of casein to produce peptides and amino acids. Cell envelope proteinase has been characterized in several LAB. Kunji (1996) divided CEP of LAB into three types based on the substrate being hydrolyzed, namely 1) CEP type PI, which hydrolyzes $\beta$-casein explicitly, 2) CEP type PIII, which hydrolyzes $\alpha$ S1-casein and $\kappa$-casein, 3) CEP type PI and PIII, hydrolyzes apart from $\beta$-casein also $\alpha$ S1- casein. Based on the results obtained in this study, the dominant peptide hydrolysis is produced from $\beta$-casein so that the CEP type from Lb. delbrueckii ssp. delbrueckii $\mathrm{BD}$ 7 is categorized into type P1 and type P1 / PIII because there are peptides released from other parent proteins. Hebert et al. (2008) previously reported the CEP type of Lb. delbrueckii subsp. lactis CRL 581 is a PI type and PI / PIII intermediate type. The specificity of Lb. delbrueckii ssp. delbrueckii $\mathrm{BD} 7$ cleavage in the parent protein was evaluated for casein protein (Figure 2). In the parent protein $\alpha \mathrm{S} 1$-casein, the dominant peptide is hydrolyzed by cleaving the amino acids Serine and Phenylalanine (S193F194, F194-S195), on aS2-casein, the amino acids Isoleucine, Glutamine, and Serine (I86-T87, I119-V120, Q116-G117), whereas for $\beta$-casein, the cleavage specificity at amino acids glutamate, Proline and Methionine (M124P125, T169-V170, P95-V96, P211-V212) and on K-casein on the amino acid Tyrosine (Y51-V52). It appears that cleavage of the parent protein occurs in certain amino acids, and it appears to be the specificity of cleavage $L b$. delbrueckii ssp. delbrueckii BD7 in casein is dominant for nonpolar/aliphatic amino acids and uncharged polar amino acids. This study's results are also in line with those reported by Hebert et al. (2008) that the cleavage specificity of Lb. delbrueckii is dominant in hydrophobic or aromatic amino acids. 


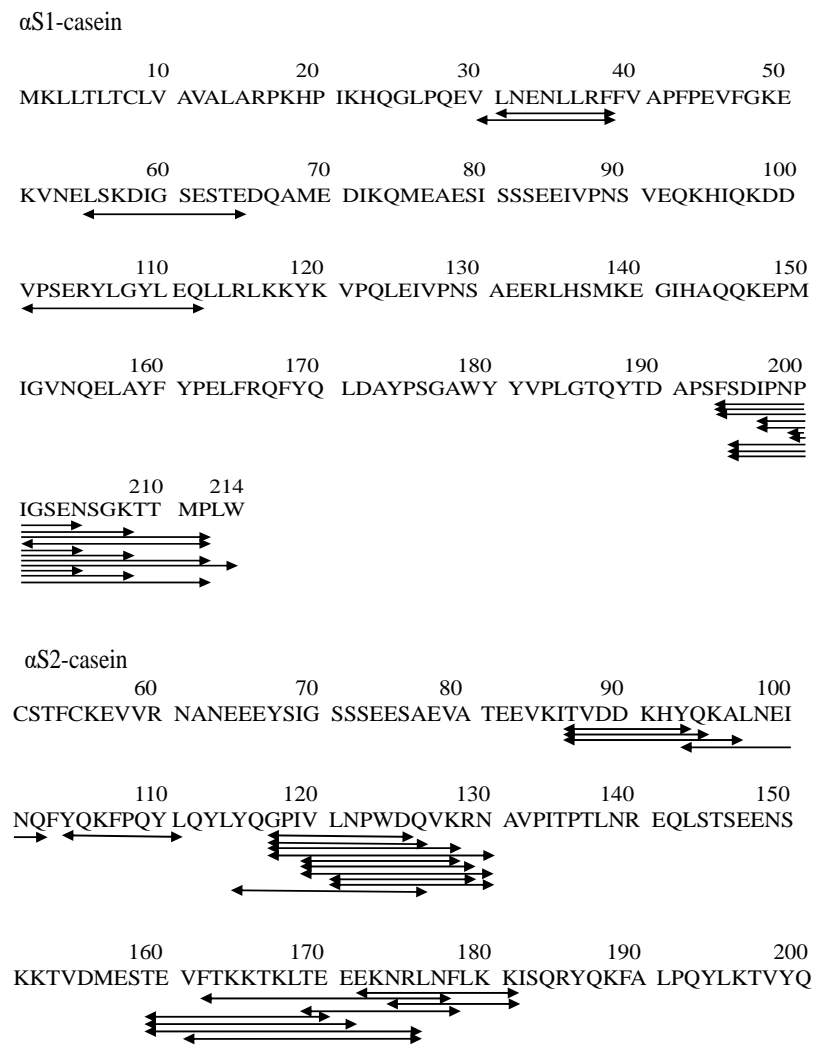

$\beta$-casein

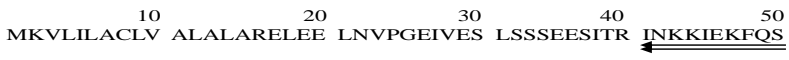
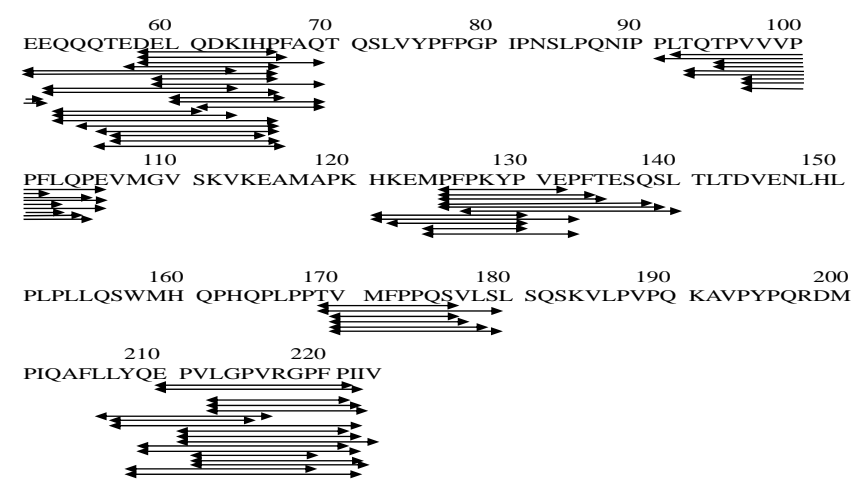

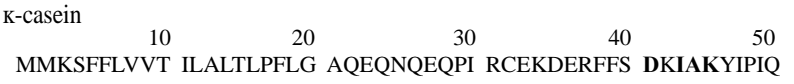

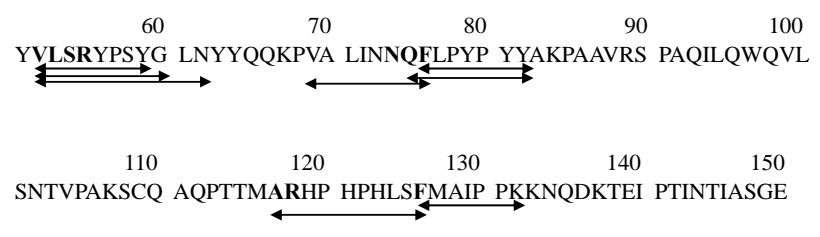

Figure 2. Specific cleavage of the parent proteins $\alpha$ s-casein, $\alpha$ s2-casein, $\beta$-casein, and $\kappa$-casein by CEP from Lb. delbrueckii ssp. delbrueckii BD7 to produce a number of peptides

\section{ACE-inhibitors peptides and other bioactive peptides in the <3 kDa fraction of goat milk fermented by $L b$. delbrueckii ssp. delbrueckii BD7}

The ACE inhibitors peptide potential of $L b$. delbrueckii ssp. delbrueckii BD7 was investigated based on a literature search. Several researchers have previously used this method to reveal the potential of peptides as bioactive peptides (Dallas et al. 2016; Georgalaki et al. 2017). In our study, peptides categorized as ACE-inhibitor peptides have similarities $(100 \%)$ in amino acid residues in the $\mathrm{C}$ terminal of the ACE inhibitor peptides. A total of 28 peptides were identified as ACE inhibitor peptides. Six of them were homologous with reported ACE inhibitor peptides namely MPFPKYPVEP ( $\beta$-casein, f124-f133), LGPVRGPFP ( $\beta$-casein, f213-221), DELQDKIHPF $(\beta$ casein, f58-f67), YQEPVLGPVRGPFPI ( $\beta$-casein, f208f222), QEPVLGPVRGPFP ( $\beta$-casein, f209-f221), and VLGPVRGPFP ( $\beta$-casein, f212-f221). It was reported that the ACE inhibitor peptide is a specific peptide, which can be identified by the presence of certain amino acids in the C-terminal. The inhibitor's binding to the ACE is strongly influenced by the hydrophobicity of the amino acid residues at the $\mathrm{C}$-terminal. ACE has three active sub-sides, namely S1 (antepenultimate), S1 '(penultimate), and S2 (ultimate). These three active sites have different characters in binding amino acid residues at the C-terminal of a peptide.
The dominant amino acid residues occupy positions one, two, or three on the C-terminal of Lb. delbrueckii ssp. delbruecki $\mathrm{BD} 7$ released peptides are the amino acids Proline, Lysine, and Phenylalanine. ACE prefers competitive substrates or inhibitors containing hydrophobic amino acids such as Proline, Lysine, and Arginine (Gútiez et al. 2013; Aslam et al. 2019). Proline is the predominant amino acid present in the C-terminal ACE-inhibitor peptide (Lu et al. 2016; Gonzalez-Gonzalez et al. 2013). In our results, 72 of the 157 peptides had Proline amino acid residues at the $\mathrm{C}$-terminal. Therefore, other peptides also have the potential as ACE inhibitor peptides. Moreover, in our results, it is known that the dominant peptide having Proline amino acid residues at the $\mathrm{C}$-terminal were derived from the parent protein $\beta$-casein, so it is not surprising that most of the ACE-inhibitor peptides were derived from $\beta$ casein. In contrast, as shown in Table 3, none of the ACEinhibitor peptides were derived from whey protein $(\alpha-$ lactalbumin, $\beta$-lactoglobulin, and serum amyloid A). Our identification of amino acid residues on the C-terminal peptide released from whey protein indicates that this position is dominated by the amino acids Asparagine, Tyrosine, and Lysine. These amino acids tend to be hydrophilic. Peptides in the presence of hydrophilic amino acids at the $\mathrm{C}$-terminal have not been widely reported to act as ACE inhibitors peptides. However, whey is also a great source of ACE inhibitor peptides (Guo et al. 2019; Ibrahim et al. 2017). 
Table 3. ACE inhibitor peptides, antioxidant peptides, and antimicrobial peptides identified in fermented goat milk by Lb. delbrueckii ssp. delbrueckii BD7 through literature search. Residues in bold letters indicate sequence homology

\begin{tabular}{|c|c|c|c|c|c|c|}
\hline $\begin{array}{r}\text { Parent } \\
\text { protein* }^{*}\end{array}$ & $\begin{array}{c}\text { Previously described } \\
\text { sequence }\end{array}$ & Sequence & $\begin{array}{l}\text { MH+ } \\
{[\mathrm{Da}]}\end{array}$ & $\mathbf{m} / \mathbf{z}[\mathrm{Da}]$ & Activity & References \\
\hline as1-CN & FSDIPNPIGSEN & FSDIPNPIGSEN & 1289.59 & 645.30 & antioxidant & $\begin{array}{l}\text { Hayes et al. (2006) } \\
\text { Rana et al. (2018) }\end{array}$ \\
\hline \multirow[t]{2}{*}{$\alpha s 1-\mathrm{CN}$} & SDIPNPIGSEN & SDIPNPIGSEN & 1142.53 & 571.77 & Antioxidant & Hayes et al. (2006) \\
\hline & & IPNPIGSEN & 940.47 & 470.74 & $\begin{array}{l}\text { Antimicrobial, } \\
\text { antioxidant }\end{array}$ & Rana et al. (2018) \\
\hline$\alpha \mathrm{s} 1-\mathrm{CN}$ & IGSENSEKTTMP & FSDIPNPIGSENSGKTTMP & 1991.92 & 996.46 & ACE inhibitory & Hayes et al. (2007) \\
\hline$\alpha s 1-\mathrm{CN}$ & & PIGSENSGKTTMP & 1318.62 & 659.81 & & \\
\hline$\alpha s 1-\mathrm{CN}$ & & IGSENSGKTTMP & 1237.57 & 619.29 & & \\
\hline$\alpha \mathrm{s} 1-\mathrm{CN}$ & TTMPLW & PIGSENSGKTTMPLW & 1617.79 & 809.40 & ACE inhibitory & Pihlanto-Leppälä et al. (1998) \\
\hline$\alpha s 2-\mathrm{CN}$ & TKKTKLTEEEKNRL & FTKKTKLTEEEKNRLN & 1979.08 & 495.52 & ACE inhibitory & Srinivas and Prakash (2010) \\
\hline$\alpha s 2-C N$ & LYQGPIVLNPWDQVK & GPIVLNPWDQVK & 1365.74 & 683.37 & ACE inhibitory & Nongonierma et al. (2017) \\
\hline$\beta-\mathrm{CN}$ & DKIHPF & LQDKIHPF & 997.54 & 499.27 & ACE inhibitory & Ibrahim et al. (2017) \\
\hline$\beta-\mathrm{CN}$ & DELQDKIHPF & DELQDKIHPF & 1241.61 & 621.31 & ACE inhibitory & Fan et al. (2018) \\
\hline$\beta-\mathrm{CN}$ & ELQDKIHPF & TEDELQDKIHPF & 1471.70 & 736.35 & ACE inhibitory & Gobbetti et al. (2000) \\
\hline$\beta-\mathrm{CN}$ & LQDKIHP & DELQDKIHP & 1094.54 & 547.77 & antioxidant & Ahmed et al. (2015) \\
\hline$\beta-\mathrm{CN}$ & DKIHP & EDELQDKIHP & 1223.58 & 612.29 & ACE inhibitory & Gobbetti et al. (2000) \\
\hline$\beta-\mathrm{CN}$ & & EEQQQTEDELQDKIHP & 1966.89 & 656.30 & & \\
\hline$\beta-\mathrm{CN}$ & & ELQDKIHP & 979.52 & 490.26 & & \\
\hline$\beta-\mathrm{CN}$ & DKIHPFAQ & LQDKIHPFAQ & 1196.63 & 598.82 & ACE inhibitory & Papadimitriou et al. (2007) \\
\hline$\beta-\mathrm{CN}$ & & ELQDKIHPFAQ & 1325.68 & 663.34 & & \\
\hline$\beta-\mathrm{CN}$ & YVPEPF & FPKYPVEPF & 1123.57 & 562.29 & antioxidant & Li et al. (2013) \\
\hline$\beta-\mathrm{CN}$ & MPFPKYPVEP & MPFPKYPVEP & 1204.60 & 602.80 & ACE inhibitory & Hayes et al. (2007) \\
\hline$\beta-\mathrm{CN}$ & & HKEMPFPKYPVEP & 1598.79 & 533.60 & & \\
\hline$\beta-\mathrm{CN}$ & & EMPFPKYPVEP & 1349.63 & 675.32 & & \\
\hline$\beta-\mathrm{CN}$ & LYQEPVLGPVRGPFPIIV & PVLGPVRGPFPIIV & 1460.89 & 730.95 & $\begin{array}{l}\text { ACE inhibitory, } \\
\text { antioxidant }\end{array}$ & Birkemo et al. (2009) \\
\hline$\beta-\mathrm{CN}$ & QEPVLGPVRGPFPIIV & & & & ACE inhibitory & Zhao et al. (2019) \\
\hline \multirow[t]{3}{*}{$\beta-\mathrm{CN}$} & YQEPVLGPVRGPFPIIV & & & & ACE inhibitory & Corrons et al. (2017) \\
\hline & & & & & antioxidant & Eisele et al. (2013) \\
\hline & & & & & antimicrobial & Birkemo et al. (2009) \\
\hline \multirow[t]{2}{*}{$\beta-\mathrm{CN}$} & GPVRGPFPIIV & & & & ACE inhibitory & Contreras et al. (2009) \\
\hline & & & & & antioxidant & Padghan et al. (2017) \\
\hline$\beta-\mathrm{CN}$ & LGPVRGPFPIIV & & & & antimicrobial & Rana et al. (2018) \\
\hline \multirow[t]{2}{*}{$\beta-\mathrm{CN}$} & YQEPVLGPVRGPFPII & QEPVLGPVRGPFPII & 1618.93 & 809.97 & antimicrobial & Birkemo et al. (2009) \\
\hline & & EPVLGPVRGPFPII & 1490.86 & 745.93 & & \\
\hline$\beta-\mathrm{CN}$ & VLGPVRGPFPII & VLGPVRGPFPII & 1264.77 & 632.89 & antimicrobial & Rana et al. (2018) \\
\hline$\beta-\mathrm{CN}$ & GVRGPFPII & & & & antioxidant & Farvin et al. (2010) \\
\hline \multirow[t]{2}{*}{$\beta-\mathrm{CN}$} & YQEPVLGPVRGPFPI & YQEPVLGPVRGPFPI & 1668.90 & 834.95 & ACE inhibitory & Torres-Llanez et al. (2011) \\
\hline & & & & & antimicrobial & Rana et al. (2018) \\
\hline$\beta-\mathrm{CN}$ & & LYQEPVLGPVRGPFPI & 1781.98 & 891.50 & & \\
\hline$\beta-\mathrm{CN}$ & GPVRGPFPI & EPVLGPVRGPFPI & 1377.78 & 689.39 & ACE inhibitory & $\begin{array}{l}\text { Hernandez-Ledesma et al. } \\
\text { (2004) }\end{array}$ \\
\hline$\beta-\mathrm{CN}$ & QEPVLGPVRGPFP & QEPVLGPVRGPFP & 1392.76 & 696.88 & ACE inhibitory & Villegas et al. (2014) \\
\hline \multirow[t]{3}{*}{$\beta-\mathrm{CN}$} & EPVLGPVRGPFP & EPVLGPVRGPFP & 1264.70 & 632.85 & Antioxidant & Padghan et al. (2017) \\
\hline & & & & & ACE inhibitory & Hayes et al. (2007) \\
\hline & & YQEPVLGPVRGPFP & 1555.82 & 778.41 & & \\
\hline \multirow[t]{2}{*}{$\beta-\mathrm{CN}$} & VLGPVRGPFP & VLGPVRGPFP & 1038.60 & 519.80 & antimicrobial & Quirós et al. (2007) \\
\hline & & & & & ACE inhibitory & Gútiez et al. (2013) \\
\hline$\beta-\mathrm{CN}$ & LGPVRGPFP & LGPVRGPFP & 939.53 & 470.27 & ACE inhibitory & Villegas et al, (2014) \\
\hline$\beta-\mathrm{CN}$ & VVVPPFLQP & VVVPPFLQP & 995.59 & 498.30 & antimicrobial & Rana et al. (2018) \\
\hline$\beta-\mathrm{CN}$ & LTQTPVVVPPFL & TQTPVVVPPFL & 1197.68 & 599.34 & antimicrobial & (Rana et al. (2018) \\
\hline$\beta-\mathrm{CN}$ & LTQTPVVVPPF & PLTQTPVVVPPF & 1294.73 & 647.87 & ACE inhibitory & Quirós et al. (2009) \\
\hline $\mathrm{K}-\mathrm{CN}$ & HPHPHLSF & ARHPHPHLSF & 1198.61 & 400.21 & antioxidant & Shanmugam et al. (2015) \\
\hline
\end{tabular}

Note: CN: Casein, A: Alanine, D: Aspartic Acid, E: GlutamicAcid, F: Phenylalanine, G: Glysin, I: Isoleucine, K: Lysine, L: Leucine, M: Methionine, N: Asparagine, P: Proline, Q: Glutamine, R: Arginine, S: Serine, T: Threonine, V: Valine, W: Tryptophan, Y: Tyrosine. ${ }^{*}$ Protein access code at https://www.uniprot.org/. 
Additionally, peptide length is also known as a characteristic of ACE inhibitor peptides. ACE inhibitor peptides are known to consist of 3 to 20 amino acids with molecular weights $<3 \mathrm{kDa}$ (Lu et al. 2016; Aslam et al. 2019). In our study, peptides with potential as ACE inhibitor peptides consisted of 8 to 19 amino acids. Short peptides are known to bind to active ACE sites easily. Short peptides with certain $\mathrm{C}$-terminal amino acid residues are known to be more resistant to gastrointestinal hydrolysis. Therefore, they do not lose their ability as ACE inhibitor peptides after oral administration (Contreras et al. 2013). In addition, short peptides are thought to be more easily transported through intestinal cells to reach the cardiovascular system. Fujita et al. (2000) have been classified ACE inhibitor peptides into three types: a) Type 1 , true inhibitor, in which the $\mathrm{IC}_{50}$ of the peptide is not affected by gastrointestinal protease or preincubation with ACE, b) Type II: Substrat type, represented by ACE inhibitors by gastrointestinal proteases, and c) Type III: pro-drug, which is peptides that are converted to potential ACE inhibitors by the action of gastrointestinal proteases (Wang et al. 2020). It is expected that the peptides produced by a starter culture are true inhibitors or prodrugs. Several ACE inhibitor peptides type 1 and III have been reported by Liu and Pischetsrieder (2017) and Quirós et al. (2009).

The peptides released in fermented milk could have more than one biological activity (Qian et al. 2011; Moreno-Montoro et al. 2018). In our study, the presence of other bioactive peptides released by $L b$. delbrueckii ssp. delbrueckii BD7 during fermentation was also identified, namely antioxidant peptides and antimicrobial peptides. The presence of antioxidant peptides in fermented foods has also attracted much attention. Increased susceptibility to disease has been associated with increased production of reactive oxygen species in plasma and cells (Guo et al. 2014). Peptides that act as antioxidant peptides could interact with radical species or inhibit oxidative reactions. Panchal et al. (2020) and Shu et al. (2018) reported the antioxidant activity in fermented foods, especially in fermented goat milk. In our study, a total of 19 peptides were identified as antioxidant peptides (Table 3). Four of them have $100 \%$ homology with antioxidant peptides that have been reported by several researchers, namely FSDIPNPIGSEN ( $\alpha$ S1-casein, f194-f205), SDIPNPIGSEN $(\alpha \mathrm{S} 1$-casein, f195-f205), EPVLGPVRGPFP ( $\beta$-casein, f210-f221), and LGPVRGPFPII ( $\beta$-casein, f213-f223). Similar to other bioactive peptides, antioxidant peptides are also characterized by their sequence and composition. Hydrophobic and aromatic amino acid residues in peptides such as the amino acids Tyrosine, Tryptophan, Methionine, and Lysine have been associated with antioxidant activity (Matsui et al. 2018). These amino acid residues were also identified in the peptide sequence released by $L b$. delbrueckii ssp. delbrueckii BD7, predominantly present in peptides released from the parent proteins $\beta$-lactoglobulin (Tyrosine and Lysine), $\kappa$-casein, and $\alpha \mathrm{S} 2$-casein (Lysine). Despite our identification results (Table 3), most antioxidant peptides were released from $\beta$-casein. However, identifying the presence of a specific amino acid in the peptide sequence can be used as a guide in determining potential peptides as antioxidant peptides.

The presence of antimicrobial peptides in our results indicates that a total of 10 peptides were identified as antimicrobial peptides. Three of them have homologous sequences with reported antimicrobial peptides (Rana et al. 2018), namely SDIPNPIGSEN ( $\alpha$ S1-casein, f195-f205), VLGPVRGPFP ( $\beta$-casein, f212-f221), and VVVPPFLQP ( $\beta$-casein, f97-f105). The presence of these peptides indicates that antimicrobial activity can be produced in fermented goat milk, in line with the results reported by Biadała et al. (2020) in goat milk fermented by $L b$. delbrueckii subsp. lactis PCM 2611 and in the research of Rana et al. (2018). Antimicrobial peptides have also been identified as short peptides. The presence of amino acid residues Glycine, Leucine, and Arginine in peptide sequences play a vital role in antimicrobial activity (Sahariah and Másson 2017; Gagnon et al. 2017).

Interestingly, from our identification results, several peptides had more than one biological activity (Table 3), namely the peptide SDIPNPIGSEN (Antioxidant and antimicrobial; $\quad \alpha$ S1-casein, f195-f205), YQEPVLGPVRGPFPI (ACE inhibitor and antimicrobial; $\beta$-casein, f208-f222), VLGPVRGPFP (ACE inhibitor and antioxidant; $\beta$-casein, f212-f221), and EPVLGPVRGPFP (ACE inhibitor and antioxidant; $\beta$-casein, f210-f221). These peptides have great uses because they can simultaneously trigger, modulate, or inhibit several physiological pathways. In the body system, it is observed that bioactivity in one area often produces beneficial effects in another (Sistla 2013; Agyei and He 2015). Peptides that have more than one biological activity have also previously been reported in research by Moreno-Montoro et al. (2018), Taha et al. (2017), and Sah et al. (2014). In particular, it appears from our identification results that the identified bioactive peptides are predominantly released from casein hydrolysis. Bioactive peptides can also be produced from whey protein hydrolysis (Dullius et al. 2018; de Lima et al. 2018). However, not many studies have demonstrated the bioactive peptide sequence of whey protein. Some of the reported peptides from whey protein do not match the peptide sequences produced in our study.

In conclusion, ACE inhibitory activity was produced in goat milk fermented by Lb. delbrueckii ssp. delbrueckii BD7. A total of 157 peptides were produced during incubation $48 \mathrm{~h}$ at $37{ }^{\circ} \mathrm{C}$. These peptides have a molecular weight ranging from 770.78 to $2081.12 \mathrm{Da}$ and consist of 7-19 amino acids. The main peptide was hydrolyzed from casein $(72.6 \%)$. Cell envelope proteinase of $L b$. delbrueckii ssp. by delbrueckii BD7 cleavage on the parent protein, specific for aliphatic and aromatic amino acids. A total of 28 ACE inhibitor peptides, 19 antioxidant peptides, and ten antimicrobial peptides were identified. Several peptides have homologous sequence with the bioactive peptides that have been reported. This study has shown ACE peptides and other bioactive peptides in goat's milk fermented by Lb. delbrueckii ssp. delbrueckii BD7. These provide an understanding that fermented goat milk is rich in benefits from its nutritional content and the biological activity of peptides produced during fermentation. Another thing is 
that using a single isolate does not reduce the benefits obtained from fermented milk. The choice of strain affects the effective release of bioactive peptides. The strain must have the right specificity to produce several bioactive peptides. Lb. delbrueckii ssp. delbrueckii BD7 has the potential as a starter culture to produce fermented milk, which is rich in biological activity.

\section{ACKNOWLEDGEMENTS}

The author would like to thank the LPDP (Lembaga Pengelola Dana Pendidikan), Ministry of Finance, Republic of Indonesia for providing research funding under Beasiswa Unggulan Dosen Indonesia Dalam Negeri. Indonesia scholarship.

\section{REFERENCES}

Abdel-Hamid M, Otte J, De Gobba C, Osman A, Hamad E. 2017. Angiotensin I-converting enzyme inhibitory activity and antioxidant capacity of bioactive peptides derived from enzymatic hydrolysis of buffalo milk proteins. Intl Dairy J 66: 91-98. DOI: 10.1016/j.idairyj.2016.11.006

Agyei D, He L. 2015. Evaluation of cross-linked enzyme aggregates of Lactobacillus cell-envelope proteinases, for protein degradation. Food Bioprod Proces 94: 59-69. DOI: 10.1016/j.fbp.2015.01.004

Ahmed AS, El-Bassiony T, Elmalt LM, Ibrahim HR. 2015. Identification of potent antioxidant bioactive peptides from goat milk proteins. Food Res Intl 74: 80-88. DOI: 10.1016/j.foodres.2015.04.032

Algboory HL, Muhialdin BJ. 2018. Identification of low molecular weight antimicrobial peptides from Iraqi camel milk fermented with Lactobacillus plantarum. Pharma Nutr 6: 69-73. DOI 10.1016/j.phanu.2018.02.002

Ali E, Nielsen SD, Abd-El Aal S, El-Leboudy A, Saleh E, LaPointe G. 2019. Use of mass spectrometry to profile peptides in whey protein isolate medium fermented by Lactobacillus helveticus LH-2 and Lactobacillus acidophilus La-5. Front Nutr 6: 152. DOI: 10.3389/fnut.2019.00152

Aslam MZ, Shoukat S, Hongfei Z, Bolin Z. 2019. Peptidomics analysis of ACE inhibitory peptides extracted from fermented goat milk. Intl J Pept Res Ther 25: 1259-1270. DOI: 10.1007/s10989-018-9771-0

Ayyash M, Al-Nuaimi AK, Al-Mahadin S, Liu SQ. 2018. In vitro investigation of anticancer and ACE-inhibiting activity, $\alpha$-amylase and $\alpha$-glucosidase inhibition, and antioxidant activity of camel milk fermented with camel milk probiotic: A comparative study with fermented bovine milk. Food Chem 239: 588-597. DOI: 10.1016/j.foodchem.2017.06.149.

Barla F, Koyanagi T, Tokuda N, Matsui H, Katayama T, Kumagai H, Michihata T, Sasaki T, Tsuji A, Enomoto T. 2016. The $\gamma$ aminobutyric acid-producing ability under low $\mathrm{pH}$ conditions of lactic acid bacteria isolated from traditional fermented foods of Ishikawa Prefecture, Japan, with a strong ability to produce ACE-inhibitory peptides. Biotechnol Rep 10: 105-110. DOI: 10.1016/j.btre.2016.04.002.

Biadała A, Szablewski T, Lasik-Kurdyś M, Cegielska-Radziejewska R 2020. Antimicrobial activity of goat's milk fermented by single strain of kefir grain microflora. Eur Food Res Technol 246: 1231-1239. DOI: $10.1007 / \mathrm{s} 00217-020-03483-2$.

Birkemo GA, O’Sullivan O, Ross RP, Hill C. 2009. Antimicrobial activity of two peptides casecidin 15 and 17, found naturally in bovine colostrum. J Appl Microbiol 106: 233-240. DOI: 10.1111/j.13652672.2008.03996.

Chaves-López C, Serio A, Paparella A, Martuscelli M, Corsetti A, Tofalo R, Suzzi G. 2014. Impact of microbial cultures on proteolysis and release of bioactive peptides in fermented milk. Food Microbiol 42: 117-121. DOI: 10.1016/j.fm.2014.03.005

Chen Y, Li C, Xue J, Kwok L, Yang J, Zhang H, Menghe B. 2015 Characterization of angiotensin-converting enzyme inhibitory activity of fermented milk produced by Lactobacillus helveticus. J Dairy Sci 98: 5113-5124. DOI: 10.3168/jds.2015-9382.

Chusman N. 1971. Spectrophotometric assay and properties of the an Iotens $\sim \mathrm{N}$-converting enzyme of rabbit lung. Biochem Pharmacol 20: 1637-1648. DOI: 10.1016/0006-2952(71)90292-9.

Contreras M del mar, Carron R, Montero MJ, Ramos M, Recio I. 2009. Novel casein-derived peptides with antihypertensive activity. Intl Dairy J 19: 566-573. DOI: 10.1016/j.idairyj.2009.05.004.

Corrons MA, Liggieri CS, Trejo SA, Bruno MA. 2017. ACE-inhibitory peptides from bovine caseins released with peptidases from Maclura pomifera latex. Food Res Intl 93: 8-15. DOI: 10.1016/j.foodres.2017.01.003.

Daliri EBM, Lee BH, Oh DH. 2017. Current trends and perspectives of bioactive peptides. Crit Rev Food Sci Nutr 93: 88-93. DOI: 10.1080/10408398.2017.1319795.

Dallas DC, Citerne F, Tian T, Silva VLM, Kalanetra KM, Frese SA, Robinson RC, Mills D A, Barile D. 2016. Peptidomics analysis reveals proteolytic activity of kefir microorganisms on bovine milk proteins. Food Chem 197: 273-284. DOI: 10.1016/j.foodchem.2015.10.116.

de Lima M dos SF, da Silva RA, da Silva MF, da Silva PAB, Costa RMPB, Teixeira JAC, Porto ALF, Cavalcanti MTH. 2018. Brazilian Kefir-fermented sheep's milk, a source of antimicrobial and antioxidant peptides. Probiotics Antimicrob Proteins 10: 446-455. DOI: $10.1007 / \mathrm{s} 12602-017-9365-8$.

Dullius A, Goettert MI, de Souza CFV. 2018. Whey protein hydrolysates as a source of bioactive peptides for functional foodsBiotechnological facilitation of industrial scale-up. J Funct Foods 42: 58-74. DOI: 10.1016/j.jff.2017.12.063.

Eisele T, Stressler T, Kranz B, Fischer L. 2013. Bioactive peptides generated in an enzyme membrane reactor using Bacillus lentus alkaline peptidase. Eur Food Res Technol 236: 483-490. DOI: 10.1007/s00217-012-1894-5.

Elfahri KR, Vasiljevic T, Yeager T, Donkor ON. 2016. Anti-colon cancer and antioxidant activities of bovine skim milk fermented by selected Lactobacillus helveticus strains. J Dairy Sci 99: 31-40. DOI: 10.3168/jds.2015-10160.

Fan H, Liao W, Wu J. 2018. Molecular interactions, bioavailability, and cellular mechanisms of angiotensin-converting enzyme inhibitory peptides. J Food Biochem 43 (1): e12572. DOI: 10.1111/jfbc. 12572.

Fan M, Guo T, Li W, Chen J, Li F, Wang C, Shi Y, Li DX, Zhang S. 2019. Isolation and identification of novel casein-derived bioactive peptides and potential functions in fermented casein with Lactobacillus helveticus. Food Sci Hum Wellness 8: 156-176. DOI 10.1016/j.fshw.2019.03.010.

Farvin KHS, Baron CP, Nielsen NS, Otte J, Jacobsen C. 2010. Antioxidant activity of yoghurt peptides: Part 2-Characterisation of peptide fractions. Food Chemi 123: 1090-1097. DOI: 10.1016/j.foodchem.2010.05.029.

Fujita H, Yokoyama K, Yoshikawa M. 2000. Classification and antihypertensive activity of angiotensin i-converting enzyme inhibitory peptides derived from food proteins. J Food Sci 65: 564569. DOI: 10.1111/j.1365-2621.2000.tb16049.

Gagnon MC, Strandberg E, Grau-Campistany A, Wadhwani P, Reichert J, Bürck J, Rabanal F, Auger M, Paquin JF, Ulrich AS. 2017. Influence of the length and charge on the activity of $\alpha$-helical amphipathic antimicrobial peptides. Biochem 56: 1680-1695. DOI: 10.1021/acs.biochem.6b01071.

Georgalaki M, Zoumpopoulou G, Mavrogonatou E, Van Driessche G, Alexandraki V, Anastasiou R, Papadelli M, Kazou M, Manolopoulou E, Kletsas D, Devreese B, Papadimitriou K, Tsakalidou E. 2017. Evaluation of the antihypertensive angiotensin-converting enzyme inhibitory (ACE-I) activity and other probiotic properties of lactic acid bacteria isolated from traditional Greek dairy products. Intl Dairy J 75: 10-21. DOI: 10.1016/j.idairyj.2017.07.003.

Gobbetti M, Ferranti P, Smacchi E, Goffredi F, Addeo F. 2000. Production of angiotensin-I-converting-enzyme-inhibitory peptides in fermented milks started by Lactobacillus delbrueckii subsp. bulgaricus SS1 and Lactococcus lactis subsp. cremoris FT4. Appl Environ Microbiol 66: 3898-3904. DOI: 10.1128/AEM.66.9.38983904.2000.

Gonzalez-Gonzalez C, Gibson T, Jauregi P. 2013. Novel probioticfermented milk with angiotensin I-converting enzyme inhibitory peptides produced by Bifidobacterium bifidum MF 20/5. Intl J Food Microbiol 167: 131-137. DOI: 10.1016/j.ijfoodmicro.2013.09.002. 
Guo Y, Zhang T, Jiang B, Miao M, Mu W. 2014. The effects of an antioxidative pentapeptide derived from chickpea protein hydrolysates on oxidative stress in Caco-2 and HT-29 cell lines. J Funct Foods 7: 719-726. DOI: 10.1016/j.jff.2013.12.013.

Guo Y, Jiang X, Xiong B, Zhang T, Zeng X, Wu Z, Sun Y, Pan D. 2019 Production and transepithelial transportation of angiotensin-Iconverting enzyme (ACE)-inhibitory peptides from whey protein hydrolyzed by immobilized Lactobacillus helveticus proteinase. J Dairy Sci 102: 961-975. DOI: 10.3168/jds.2018-14899.

Gútiez L, Gómez-Sala B, Recio I, del Campo R, Cintas LM, Herranz C, Hernández PE. 2013. Enterococcus faecalis strains from food, environmental, and clinical origin produce ACE-inhibitory peptides and other bioactive peptides during growth in bovine skim milk. Intl J Food Microbiol 166: 93-101. DOI: 10.1016/j.ijfoodmicro.2013.06.019.

Hayes M, Ross RP, Fitzgerald GF, Hill C, Stanton C. 2006. Caseinderived antimicrobial peptides generated by Lactobacillus acidophilus DPC6026. Appl Environ Microbiol 72: 2260-2264. DOI: 10.1128/AEM.72.3.2260-2264.2006

Hayes M, Stanton C, Slattery H, Sullivan OO, Hill C, Fitzgerald GF, Ross RP. 2007. Casein Fermentate of Lactobacillus animalis DPC6134 contains a range of novel propeptide angiotensin-converting enzyme inhibitors. Appl Environ Microbiol 73: 4658-4667. DOI: 10.1128/AEM.00096-07.

Hebert EM, Mamone G, Picariello G, Raya RR, Savoy G, Ferranti P, Addeo F. 2008. Characterization of the pattern of $\alpha$ s1-and $\beta$-casein breakdown and release of a bioactive peptide by a cell envelope proteinase from Lactobacillus delbrueckii subsp. lactis CRL 581. Appl Environ Microbiol 74: 3682-3689. DOI: 10.1128/AEM.0024708 .

Hernandez-Ledesma B, Amigo L, Ramos M, Recio I. 2004. Angiotensin converting enzyme inhibitory activity in commercial fermented products. Formation of peptides under simulated gastrointestinal digestion. J Agric Food Chem 52: 1504-1510. DOI: 10.1021/jf034997b.

Ibrahim HR, Ahmed AS, Miyata T. 2017. Novel angiotensin-converting enzyme inhibitory peptides from caseins and whey proteins of goat milk. J Adv Res 8: 63-71. DOI: 10.1016/j.jare.2016.12.002.

Izquierdo-González JJ, Amil-Ruiz F, Zazzu S, Sánchez-Lucas R, FuentesAlmagro CA, Rodríguez-Ortega MJ. 2019. Proteomic analysis of goat milk kefir: Profiling the fermentation-time dependent protein digestion and identification of potential peptides with biological activity. Food Chem 295: 456-465. DOI: 10.1016/j.foodchem.2019.05.178.

Ji D, Ma J, Xu M, Agyei D. 2021. Cell-envelope proteinases from lactic acid bacteria: Biochemical features and biotechnological applications. Compr Rev Food Sci Food Saf 20: 369-400. DOI: 10.1111/15414337.12676.

Karami Z, Akbari-Adergani B. 2019. Bioactive food-derived peptides: a review on correlation between structure of bioactive peptides and their functional properties. 2019. J Food Sci Technol 56: 535-547. DOI: $10.1007 / \mathrm{s} 13197-018-3549-4$.

Kim HJ, Kang SG, Jaiswal L, Li J, Choi JH, Moon SM, Cho JY, Ham KS 2016. Identification of four new angiotensin I-converting enzyme inhibitory peptides from fermented anchovy sauce. Appl Biol Chem 59: 25-31. DOI: $10.1007 / \mathrm{s} 13765-015-0129-4$

Kliche T, Li B, Bockelmann W, Habermann D, Klempt M, de Vrese M, Wutkowski A, Clawin-Raedecker I, Heller KJ. 2017. Screening for proteolytically active lactic acid bacteria and bioactivity of peptide hydrolysates obtained with selected strains. Appl Microbiol Biotechnol 101: 7621-7633. DOI: 10.1007/s00253-017-8369-3.

Kunji ERS. 1996. The proteolytic systems of lactic acid bacteria. Antonie van Leeuwenhoek 70: 187-221. DOI: 10.1007/BF00395933.

Li C, Kwok LY, Mi Z, Bala J, Xue J, Yang J, Ma Y, Zhang H, Chen Y. 2017. Characterization of the angiotensin-converting enzyme inhibitory activity of fermented milks produced with Lactobacillus casei. J Dairy Sci 100: 9495-9507. DOI: 10.3168/jds.2017-12970.

Li S, Tang S, He Q, Hu J, Zheng J. 2019. Changes in proteolysis in fermented milk produced by Streptococcus thermophilus in Coculture with Lactobacillus plantarum or Bifidobacterium animalis subsp. lactis during refrigerated storage. Molecules 24: 3699. DOI: 10.3390/molecules24203699.

Li Z, Jiang A, Yue T, Wang J, Wang Y, Su J. 2013. Purification and identification of five novel antioxidant peptides from goat milk casein hydrolysates. J Dairy Sci 96: 4242-4251. DOI:10.3168/jds.2012-6511
Liu Y, Pischetsrieder M. 2017. Identification and relative quantification of bioactive peptides sequentially released during simulated gastrointestinal digestion of comersial Kefir. J Agric Food Chem 65: 1865-1873. DOI: 10.1021/acs.jafc.6b05385.

Lozo J, Strahinic I, Dalgalarrondo M, Chobert JM, Haertlé T, Topisirovic L. 2011. Comparative analysis of $\beta$-casein proteolysis by PrtP proteinase from Lactobacillus paracasei subsp. paracasei BGHN14, PrtR proteinase from Lactobacillus rhamnosus BGT10 and PrtH proteinase from Lactobacillus helveticus BGRA43. I Dairy J 21: 863868. DOI: 10.1016/j.idairyj.2011.05.002.

Lu Y, Govindasamy-Lucey S, Lucey JA. 2016. Angiotensin-I-converting enzyme-inhibitory peptides in commercial Wisconsin cheddar cheeses of different ages. J Dairy Sci 99: 41-52. DOI: 10.3168/jds.2015-9569.

Matsui R, Honda R, Kanome M, Hagiwara A, Matsuda Y, Togitani T, Ikemoto N, Terashima M. 2018. Designing antioxidant peptides based on the antioxidant properties of the amino acid side-chains. Food Chem 245: 750-755. DOI: 10.1016/j.foodchem.2017.11.119.

Meisel H, Bockelmann W. 1999. Bioactive peptides encrypted in milk proteins: Proteolytic activation and thropho-functional properties. Lactic Acid Bacteria: Gen Metabol Appl 76: 207-215. DOI: 10.1007/978-94-017-2027-4 10.

Moreno-Montoro M, Jauregi P, Navarro-Alarcón M, Olalla-Herrera M, Giménez-Martínez R, Amigo L, Miralles B. 2018. Bioaccessible peptides released by in vitro gastrointestinal digestion of fermented goat milks. Anal Bioanal Chem 410: 3597-3606. DOI: 10.1007/s00216-018-0983-0.

Nongonierma AB, Paolella S, Mudgil P, Maqsood S, FitzGerald R J. 2017. Dipeptidyl peptidase IV (DPP-IV) inhibitory properties of camel milk protein hydrolysates generated with trypsin. J Funct Foods 34: 49-58. DOI: 10.1016/j.jff.2017.04.016.

Padghan PV, Mann B, Sharma R, Bajaj R, Saini P. 2017. Production of angiotensin-i-converting-enzyme-inhibitory peptides in fermented milks (Lassi) fermented by Lactobacillus acidophillus with consideration of incubation period and simmering treatment. Intl $\mathbf{J}$ Pept Res Ther 23: 69-79. DOI: 10.1007/s10989-016-9540-x.

Panchal G, Hati S, Darji V, Prajapati J. 2020. Antioxidant activities, proteolytic activity and growth behavior of Lactobacillus cultures during fermentation of goat milk. Ind J Dairy Sci 73: 57-66. DOI: 10.33785/ijds.2020.v73i01.010

Papadimitriou CG, Vafopoulou-Mastrojiannaki A, Silva SV, Gomes AM, Malcata FX, Alichanidis E. 2007. Identification of peptides in traditional and probiotic sheep milk yoghurt with angiotensin Iconverting enzyme (ACE)-inhibitory activity. Food Chem 105: 647656. DOI: 10.1016/j.foodchem.2007.04.028

Pihlanto-Leppälä A, Rokka T, Korhonen H. 1998. Angiotensin I converting enzyme inhibitory peptides derived from bovine milk proteins. Intl Dairy J 8: 325-331. DOI: 10.1016/S09586946(98)00048-X.

Qian B, Xing M, Cui L, Deng Y, Xu Y, Huang M, Zhang S. 2011. Antioxidant, antihypertensive, and immunomodulatory activities of peptide fractions from fermented skim milk with Lactobacillus delbrueckii ssp. bulgaricus LB340. J Dairy Res 78: 72-79. DOI: 10.1017/S0022029910000889.

Quirós A, Contreras M del M, Ramos M, Amigo L, Recio I. 2009. Stability to gastrointestinal enzymes and structure-activity relationship of $\beta$-casein-peptides with antihypertensive properties. Peptides 30: 1848-1853. DOI: 10.1016/j.peptides.2009.06.031.

Quirós A, Ramos M, Muguerza B, Delgado MA, Miguel M, Aleixandre A, Recio I. 2007. Identification of novel antihypertensive peptides in milk fermented with Enterococcus faecalis. Intl Dairy J 17: 33-41. DOI: 10.1016/j.idairyj.2005.12.011.

Rai AK, Sanjukta S, Jeyaram K. 2017. Production of angiotensin I converting enzyme inhibitory (ACE-I) peptides during milk fermentation and their role in reducing hypertension. Crit Rev Food Sci Nutr 57: 2789-2800. DOI: 10.1080/10408398.2015.1068736.

Rana S, Bajaj R, Mann B. 2018. Characterization of antimicrobial and antioxidative peptides synthesized by L. rhamnosus C6 fermentation of milk. Intl J Pept Res Ther 24: 309-321. DOI: 10.1007/s10989-0179616-2.

Raveschot C, Cudennec B, Deracinois B, Frémont M, Vaeremans M, Dugersuren J, Demberel S, Drider D, Dhulster P, Coutte F, Flahaut C. 2020. Proteolytic activity of Lactobacillus strains isolated from Mongolian traditional dairy products: A multiparametric analysis. Food Chem 304: 125415. DOI: 10.1016/j.foodchem.2019.125415.

Retnaningrum E, Yossi T, Nur'azizah R, Sapalina F, Kulla PDK. 2020. Characterization of a bacteriocin as biopreservative synthesized by 
indigenous lactic acid bacteria from dadih soya traditional product used in West Sumatra, Indonesia. Biodiversitas 21: 4192-4198. DOI: 10.13057/biodiv/d210933.

Rubak YT, Nuraida L, Iswantini D, Prangdimurti E. 2020. Angiotensin-Iconverting enzyme inhibitory peptides in milk fermented by indigenous lactic acid bacteria. Vet World 13: 345-353. DOI: 10.14202/vetworld.2020.345-353.

Sah BNP, Vasiljevic T, McKechnie S, Donkor ON. 2014. Effect of probiotics on antioxidant and antimutagenic activities of crude peptide extract from yogurt. Food Chem 156: 264-270. DOI: 10.1016/j.foodchem.2014.01.105

Sahariah P, Másson M. 2017. Antimicrobial chitosan and chitosan derivatives: A review of the structure-activity relationship. Biomacromol 18: 3846-3868. DOI: 10.1021/acs.biomac.7b01058.

Savijoki K, Ingmer H, Varmanen P. 2006. Proteolytic systems of lactic acid bacteria. Appl Microbiol Biotechnol 71: 394-406. DOI 10.1007/s00253-006-0427-1.

Selvaggi M, Laudadio V, Dario C, Tufarelli V. 2014. Major proteins in goat milk: An updated overview on genetic variability. Mol Biol Rep 41: 1035-1048. DOI: 10.1007/s11033-013-2949-9.

Shanmugam VP, Kapila S, Sonfack TK, Kapila R. 2015. Antioxidative peptide derived from enzymatic digestion of buffalo casein. Intl Dairy J 42: 1-5. DOI: 10.1016/j.idairyj.2014.11.001.

Shi M, Ahtesh F, Mathai M, McAinch AJ, Su XQ. 2017. Effects of fermentation conditions on the potential anti-hypertensive peptides released from yogurt fermented by Lactobacillus helveticus and Flavourzyme. Intl J Food Sci Technol 52: 137-145. DOI: 10.1111/ijfs.13253.

Shu G, Huang J, Bao C, Meng J, Chen H, Cao J. 2018. Effect of different proteases on the degree of hydrolysis and angiotensin I-converting enzyme-inhibitory activity in goat and cow milk. Biomolecules 8: 101. DOI: 10.3390/biom8040101.

Shu G, Shi X, Chen H, Ji Z, Meng J. 2019. Optimization of nutrient composition for producing ACE inhibitory peptides from goat milk fermented by Lactobacillus bulgaricus LB6. Probiotics Antimicrob Proteins 11: 723-729. DOI: 10.1007/s12602-018-9410-2.

Shu G, Yang H, Chen H, Zhang Q, Tian Y. 2015. Effect of incubation time, inoculum size, temperature, pasteurization time, goat milk powder and whey powder on ace inhibitory activity in fermented milk by L. Plantarum LP69. Acta Sci Pol Technol Aliment 14: 107-116. DOI: 10.17306/J.AFS.2015.2.12.

Sistla S. 2013. Structure-activity relationships of $\alpha$ s-casein peptides with multifunctional biological activities. Mol Cell Biochem 384: 29-38. DOI: $10.1007 / \mathrm{s} 11010-013-1778-4$.

Srinivas S, Prakash V. 2010. Bioactive peptides from bovine milk $\alpha$ casein: Isolation, characterization and multifunctional properties. Intl J Pept Res Ther 16: 7-15. DOI: 10.1007/s10989-009-9196-x.
Taha S, El Abd M, De Gobba C, Abdel-Hamid M, Khalil E, Hassan D. 2017. Antioxidant and antibacterial activities of bioactive peptides in buffalo's yoghurt fermented with different starter cultures. Food Sci Biotechnol 26: 1325-1332. DOI: 10.1007/s10068-017-0160-9.

Torres-Llanez MJ, González-Córdova AF, Hernandez-Mendoza A, Garcia HS, Vallejo-Cordoba B. 2011. Angiotensin-converting enzyme inhibitory activity in Mexican Fresco cheese. J Dairy Sci 94: 37943800. DOI: $10.3168 /$ jds.2011-4237.

Villegas JM, Brown L, Savoy de Giori G, Hebert EM. 2015. Characterization of the mature cell-surface proteinase of Lactobacillus delbrueckii subsp. lactis CRL 581. Appl Microbiol Biotechnol 99: 4277-4286. DOI: 10.1007/s00253-014-6258-6.

Villegas JM, Picariello G, Mamone G, Beatriz M, Turbay E, Giori GS. De, Hebert EM. 2014. Milk-derived angiotensin-I-converting enzymeinhibitory peptides generated by Lactobacillus delbrueckii subsp. lactis CRL 581. Peptidomics 1: 22-29. DOI: 10.2478/ped2014-0002.

Wang H, Meng F, Yin L, Cheng Y, Lu A, Wang J. 2016. Changes of composition and angiotensin i-converting enzyme-inhibitory activity during douchi fermentation. Intl J Food Prop 19: 2408-2416. DOI: 10.1080/10942912.2015.1040122.

Wang J, Li C, Xue J, Yang J, Zhang Q, Zhang H, Chen Y. 2015. Fermentation characteristics and angiotensin I-converting enzymeinhibitory activity of Lactobacillus helveticus isolate H9 in cow milk, soy milk, and mare milk. J Dairy Sci 98: 3655-3664. DOI: 10.3168/jds.2015-9336.

Wang R, Lu X, Sun Q, Gao J, Ma L, Huang J. 2020. Novel ACE inhibitory peptides derived from simulated gastrointestinal digestion in vitro of sesame (Sesamum indicum L.) protein and molecular docking study. Intl J Mol Sci 21: 1059. DOI: 10.3390/ijms21031059.

Wu N, Xu W, Liu K, Xia Y, Shuangquan. 2019. Angiotensin-converting enzyme inhibitory peptides from Lactobacillus delbrueckii QS306 fermented milk. J Dairy Sci 102: 5913-5921. DOI: 10.3168/jds.201815901.

Zhao H, Zhou F, Wang L, Fengling B, Dziugan P, Walczak P, Zhang B. 2014. Characterization of a bioactive peptide with cytomodulatory effect released from casein. Eur Food Res Technol 238:315-322. DOI: 10.1007/s00217-013-2106-7.

Zhao L, Cai X, Huang S, Wang S, Huang Y, Hong J, Rao P. 2015. Isolation and identification of a whey protein-sourced calciumbinding tripeptide Tyr-Asp-Thr. Intl Dairy J 40: 16-23. DOI: 10.1016/j.idairyj.2014.08.013.

Zhao YQ, Zhang L, Tao J, Chi CF, Wang B. 2019. Eight antihypertensive peptides from the protein hydrolysate of Antarctic krill (Euphausia superba): Isolation, identification, and activity evaluation on human umbilical vein endothelial cells (HUVECs). Food Res Intl 121: 197204. DOI: 10.1016/j.foodres.2019.03.035. 